\title{
Calle litiásica espontanea autorresuelta
}

\author{
Collado Serra A*, Menéndez López V**, Galán Llopis JA***, García López $\mathrm{F}^{* * * *}$. \\ *Servicio de Urología. Instituto Valenciano de Oncología. Valencia.**Servicio y Cátedra de Urología. Hospital \\ del Mar. UAB. Barcelona. ${ }^{* * *}$ Servicio de Urología. Hospital General de Alicante. Alicante. \\ ****Servicio de Urología. Hospital General Universitario de Elche. Alicante.
}

Actas Urol Esp. 2007;31(5):572

$\mathrm{P}$ aciente de 63 años de edad sin antecedentes patológicos de interés ni antecedentes de litiasis renal. Acude a consulta para valoración de episodios autolimitados de dolor lumbar derecho. Se practica radiografía abdómino-pélvica (imágenes cálcicas en silueta renal y trayecto ureteral derecho) y ecografía reno-vesical (litiasis renal derecha múltiple que condiciona severa ectasia). La urografia endovenosa objetiva notable retraso funcional riñón derecho (Fig. 1).

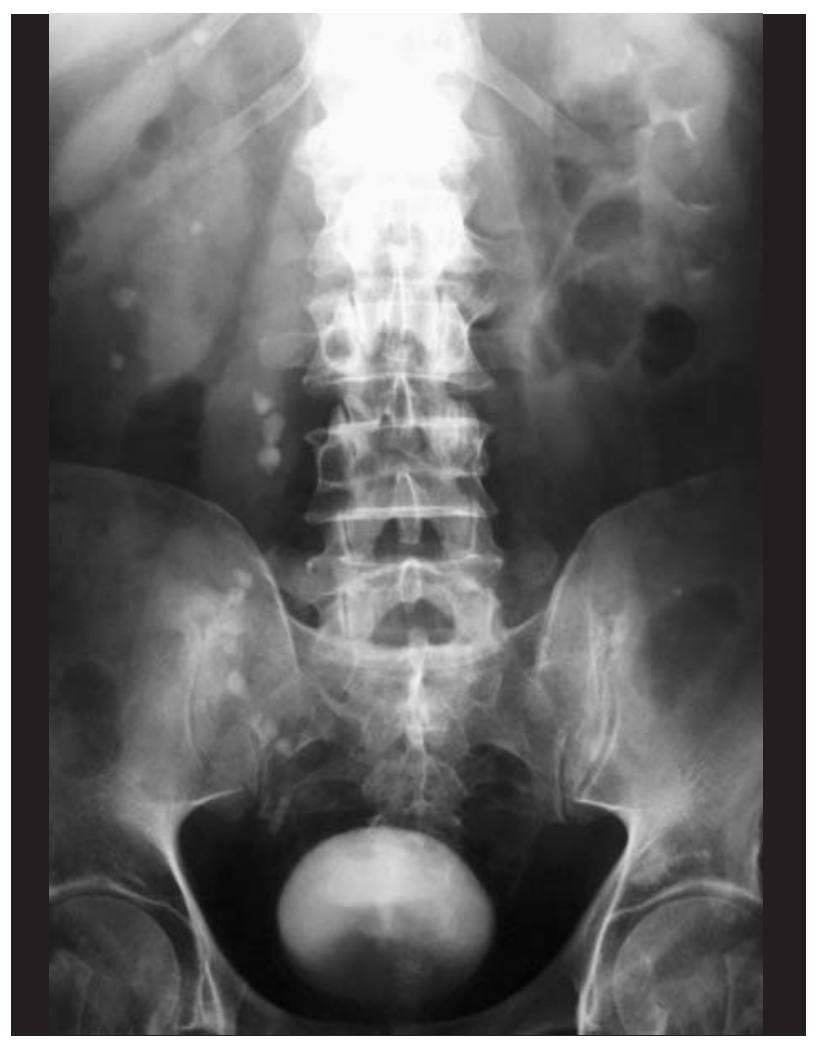

FIGURA 1

Pendiente de decisión clínica, el paciente acude refiriendo cólico nefrítico y expulsión espontánea de múltiples litiasis (Fig. 2). Se realiza nueva uro-

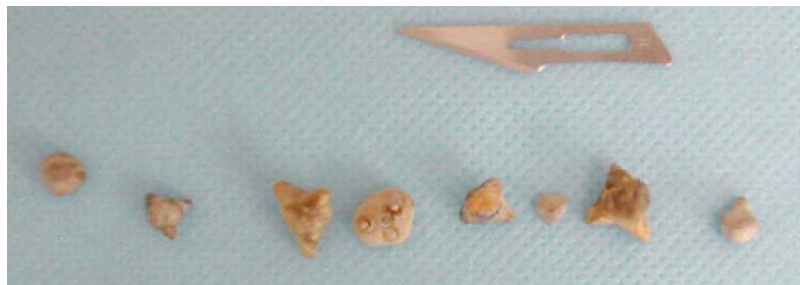

\section{FIGURA 2}

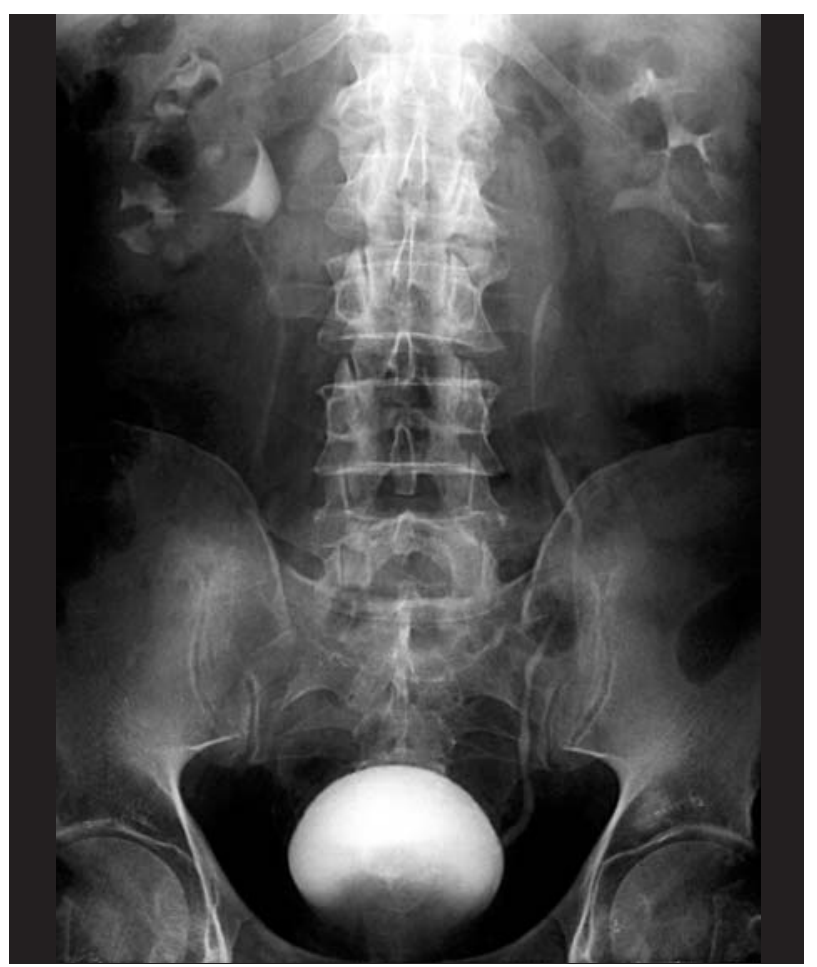

FIGURA 3

grafia, evidenciando normofunción renal bilateral y ausencia de litiasis, tanto en riñón como en uréter (Fig. 3).

Correspondencia autor: Dr. A. Collado Serra

Instituto Valenciano de Oncología. Profesor Beltrán Báguena, 19 46009 Valencia Tel.: 961114000

E-mail autor: argimirocollado@usa.net

Información artículo: Imágenes en Urología

Trabajo recibido: abril 2006

Trabajo aceptado: mayo 2006 